\title{
The role of silicon in suppressing gray leaf spot development in St. Augustinegrass 1
}

\section{Brecht, L. Datnoff, R. Nagata \& T. Kucharek ${ }^{2}$}

If you maintain St. Augustinegrass

(Stenotaphrum secundatum) in Florida, its possible that gray leaf spot, caused by the fungus

Magnaporthe grisea (Pyricularia grisea), will be a problem in your lawn or sod field. Warm

temperatures and wet weather are ideal conditions for the telltale, grayish, oblong spots that form on leaves and stolons. High nitrogen fertilizer and improper use of herbicides also can enhance this disease. The disease can cause leaves and stolons to die and make entire plantings appear scorched (Figure 1). Damage by gray leaf spot in St. Augustinegrass is most severe in newly sprigged lawns, and new and regenerating sod fields. Gray leaf spot has been shown to reduce the ground coverage of sprigged areas by 35.5 percent (Freeman, 1962), which often delays the grow-in phase and increases the likelihood of a weed infestation.

Currently, gray leaf spot in St. Augustinegrass may be managed by the use of partially resistant cultivars, or spraying with a fungicide such as chlorothalonil every 7 to 14 days. With the increasing concern about pesticides and cost, and the lack of highly resistant cultivars with good horticultural

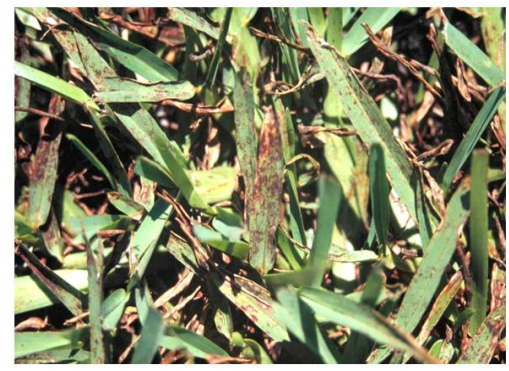

Figure 1. Leaf scorching and death of St. Augustinegrass caused by gray leaf spot. Credits: M. Brecht

quality, alternative methods to control this plant disease are needed. Research has proven the effectiveness of amendments of silicon ( $\mathrm{Si}$ ) to soils that are deficient in soluble $\mathrm{Si}(<25 \mathrm{mg} / \mathrm{L})$ for control of diseases on a number of hosts including rice and sugarcane, which are regularly fertilized with $\mathrm{Si}$ in south Florida (Figure 2).

Silicon is not generally considered an essential plant nutrient, but dry-land species of Gramineae, such as sugarcane, most cereal species, grasses, and some dicots contain about $1-3 \% \mathrm{Si}$ in dry matter. This is not surprising since most plants contain at

1. This document is PP-67, one of a series of the Plant Pathology Department, Florida Cooperative Extension Service, Institute of Food and Agricultural Sciences, University of Florida. Publication date: July, 2003. Please visit the EDIS Web site at http:/edis.ifas.ufl.edu

2. M. Brecht, Graduate Research Assistant, Department of Plant Pathology, University of Florida, Gainesville, FL 32611, L. Datnoff, Professor, Department of Plant Pathology, University of Florida-IFAS, Everglades Research and Education Center, Belle Glade, FL 33430, R. Nagata, Associate Professor, Department of Horticulture, University of Florida-IFAS, Everglades Research and Education Center, Belle Glade, FL 33430 and T. Kucharek, Professor, Department of Plant Pathology, University of Florida, Gainesville, FL 32611.

The Institute of Food and Agricultural Sciences is an equal opportunity/affirmative action employer authorized to provide research, educational information and other services only to individuals and institutions that function without regard to race, color, sex, age, handicap, or national origin. For information on obtaining other extension publications, contact your county Cooperative Extension Service office. Florida Cooperative Extension Service/Institute of Food and Agricultural Sciences/University of Florida/Christine Taylor Waddill, Dean. 


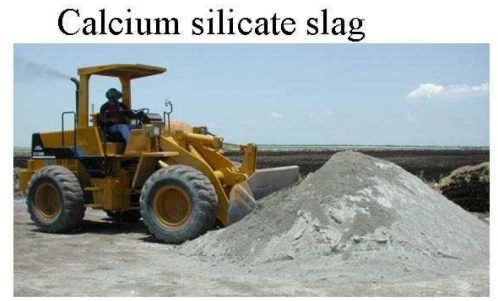

Figure 2. Pile of calcium silicate slag being collected for field application. Credits: M. Brecht

least some amount of almost all the elements present in the soil solution. At present, $\mathrm{Si}$ is an essential element for diatoms and other members of the Chrysophyceae (yellow-brown or golden-brown algae) and Equisitaceae (horsetails). However, many plants deprived of Si suffer significant reductions in growth and crop yield as well as increased susceptibility to both biotic and abiotic stresses (Datnoff et al., 2001). In uncultivated natural settings, the removal of Si from the soil solution by plants is replenished sufficiently by chemical weathering of soil silicates, desorption from soil surfaces, and by recycling from plant residues. However, continuously cultivated agricultural fields may often be very low in plant available $\mathrm{Si}$. Calculations, from a sugarcane field in south Florida, determined that nearly $100 \mathrm{~kg} / \mathrm{ha}$ of $\mathrm{Si}$ is removed from the soil each harvest cycle (Savant et al., 1999). The primary mineral form of $\mathrm{Si}$ (quartz, $\mathrm{SiO}_{2}$, being the most common) is stable and does not weather as quickly as the clay silicates. As plants absorb monosilicic acid $\left[\mathrm{Si}(\mathrm{OH})_{4}\right]$ from the soil solution, it is then carried by the transpiration stream and deposited in the plant tissues mainly as amorphous silica gel $\left(\mathrm{SiO}_{2} n \mathrm{H}_{2} 0\right)$.

Fertilization of rice and sugarcane with $\mathrm{Si}$ increases yields by increasing growth; mineral nutrition; mechanical strength; and resistance to mineral toxicities, biotic, and abiotic stresses (Datnoff et al., 1997; Savant et al., 1999). Silicon has also been shown to have positive effects in various turfgrasses such as zoysia, Kentucky bluegrass, and bentgrass (Hamel and Heckman, 1999; Linjuan et al., 1999). Turfgrass quality, growth and resistance to traffic and heat stress were increased in creeping bentgrass and zoysia grass cultivars by fertilization with Si (Linjuan et al., 1999). Recently, Datnoff and Nagata (1999) showed that an amendment of calcium silicate slag reduced gray leaf spot disease dramatically on several cultivars of St.

Augustinegrass.

A replicated study was conducted to evaluate if gray leaf spot in St. Augustinegrass could be managed with Si fertilization under field conditions. Field experiments were conducted in the summer of 2000 at two locations, King Ranch and Woerner Turf Farm, located in the Everglades Agricultural Area of South Florida. Both sites had Si-deficient Histosols (between 10 to $14 \mathrm{ppm}(\mathrm{mg} / \mathrm{L})$ extractable $\mathrm{Si}$ ). The experimental design at both locations was a randomized complete block with four replications and a plot size of $15.3 \times 122$ meter. The treatments included Si alone, chlorothalonil $(\mathrm{CH})$ alone, Si plus $\mathrm{CH}$, and a non-treated control (no $\mathrm{Si}$ and no $\mathrm{CH}$ ). Silicon, applied as calcium silicate slag $\left(\mathrm{CaSiO}_{3}\right.$, Calcium Silicates Corporation, Inc., Lake Harbor, FL), was soil-incorporated at $5000 \mathrm{~kg} / \mathrm{ha}$. Applications of CH (Daconil Weather Stik, Syngenta) were made every 10 days at $10.2 \mathrm{~L} / \mathrm{ha}$. St. Augustinegrass, cultivar Floratam, was plugged and maintained by the grower according to current sod production practices. Severity of gray leaf spot for the whole plant was recorded weekly as percent leaf area diseased, starting three weeks after plugging the field. A percent bare ground coverage rating was recorded 11 to12 weeks after plugging the field. Six ratings were recorded every 15 meters per experimental unit (plot) by estimating a visual percent area of bare ground covered by grass in a 2 square meter area.

Environmental conditions for disease development and plant growth were favorable at both locations. However, the Worener Field location had a greater amount of overall disease in comparison to the King Ranch (Figure 3). Gray leaf spot development, when compared to the non-treated control, was reduced by $17-27,31-63$, and $56-64 \%$ for Si alone, chlorothalonil, and Si plus chlorothalonil at both sites, respectively (Figure 3). At high disease levels, such as those at the Woerner Turf site, Si performed as well as the fungicide. The combination of $\mathrm{Si}+\mathrm{CH}$ had an additive effect. Final percent bare ground coverage was significantly increased using $\mathrm{Si}$ 
by 17 to $34 \%$ over the control at both field sites (Figure 4).

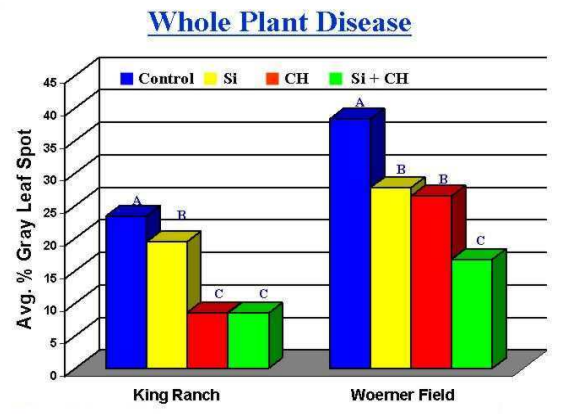

Figure 3. Average \% gray leaf spot development in whole plants treated with silicon $(\mathrm{Si})$, chlorothalonil $(\mathrm{CH})$ or Si plus $\mathrm{CH}$ at two field sites. Bars with the same letter within the same field site do not differ significantly at $\mathrm{P}=0.05$ as determined by Fisher's protected LSD test. Credits: M. Brecht

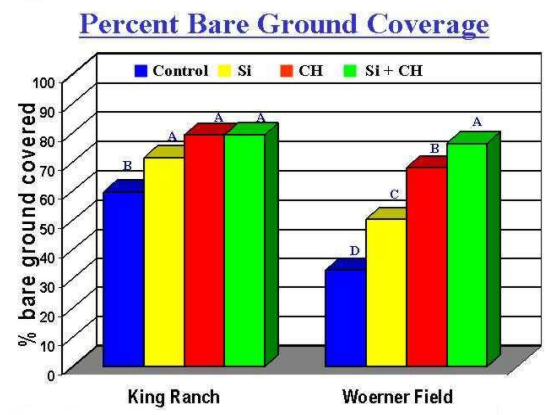

Figure 4. Percent bare ground coverage in St. Augustinegrass treated with silicon (Si), Chlorothalonil $(\mathrm{CH})$ or Si plus $\mathrm{CH}$ at two field sites. Bars with the same letter within the same field site do not differ significantly at $\mathrm{P}=0.05$ as determined by Fisher's protected LSD test. Credits: M. Brecht

Calcium silicate slag did not alter the $\mathrm{pH}$ (6.3) of the soil and the Si concentration was increased to $133 \mathrm{ppm}(\mathrm{mg} / \mathrm{L})$ in the soil. The control had significantly higher concentrations of $\mathrm{Ca}$ and $\mathrm{Mg}$ in plant tissue in comparison to the calcium silicate treatments. Silicon also increased in the plant tissue but only in the treatments that received calcium silicate, and this increase was double that of the non-treated control (Figure 5).

To understand how Si reduces gray leaf spot development in St. Augustinegrass, it is necessary to
Plant Nutrient Analysis

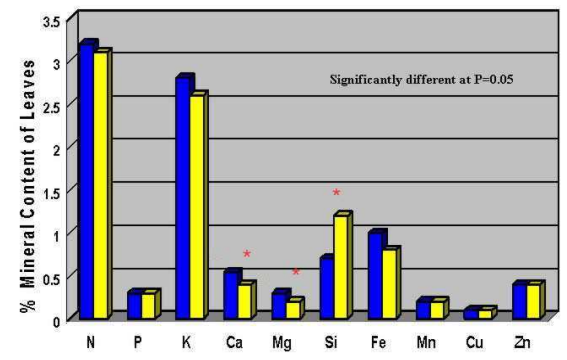

Figure 5. Percent mineral content in leaf tissue of St. Augustinegrass. Credits: M. Brecht

study how Si influences the components of host plant resistance. Components of resistance include incubation period (time it takes a spore to land on a leaf surface and exhibit visible symptoms of the disease), latent period (time it takes for $60 \%$ of the lesions to produce spores), lesion number, lesion area, daily rate of lesion expansion, and spore number produced per lesion. All of these components of resistance contribute to disease development, and if one or more of these components can be interrupted or contained, then the maximum amount of disease that can occur will be reduced. A replicated greenhouse study was conducted to test six rates $(0$, $0.5,1,2,5,10 \mathrm{MT} / \mathrm{ha}$ ) of calcium silicate slag and evaluate their ability to affect different resistance components (such as number of lesions produced) to gray leaf spot in the St. Augustinegrass cultivars Floratam and FX-10. The 5 and $10 \mathrm{MT} /$ ha treatments significantly reduced the number of lesions produced in both cultivars by $44-63 \%$ when compared to the untreated control (Figure 6). By reducing the total number of lesions produced, the total number of spores produced also is dramatically reduced. This will slow down the epidemic of gray leaf spot especially in the field. Percent leaf area diseased, which was reduced as a direct result of the lower numbers of lesions produced, progressively decreased as the amount of $\mathrm{Si}$ in the leaf tissue increased (Figure 7). It seems that Si acts to either reduce the number of susceptible sites on the leaf and/or aids in the resistance to colonization of the gray leaf spot fungus. Thus, $\mathrm{Si}$ increases the resistance to infection in St. Augustinegrass, which in turn reduces the number of lesions produced, the number of spores produced and, consequently, the epidemic development of gray leaf spot. 


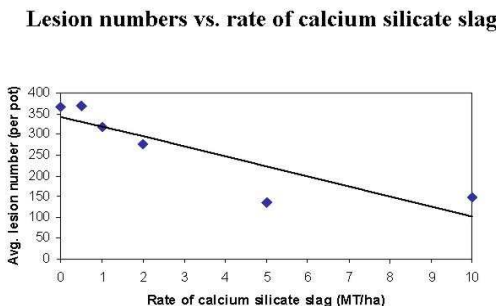

Figure 6. Influence of calcium silicate slag rates on average number of gray leaf spot lesions. Credits: $\mathrm{M}$. Brecht

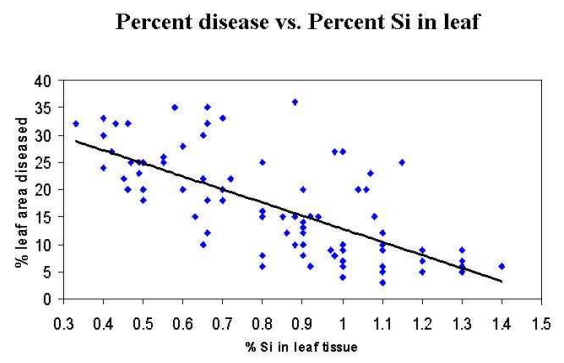

Figure 7. The relationship between silicon (Si) content in leaf tissue and the \% leaf area diseased (gray leaf spot). Credits: M. Brecht

In the case of St. Augustinegrass, Si appears to be a viable method for increasing prostrate growth and reducing gray leaf spot development. Even under conditions of high inoculum pressure, Si can suppress gray leaf spot development as effectively as a fungicide. Silicon may therefore help in the management of fungicide use, thus promoting good environmental stewardship. The use of $\mathrm{Si}$ amendments for St. Augustinegrass, especially on soils that are deemed low in this element, may be a good option for reducing plant diseases including gray leaf spot for commercial sod growers and homeowners.

\section{References:}

Datnoff, L.E., Deren, C.W., and Snyder, G.H. 1997. Silicon fertilization for disease management of rice in Florida. Crop Protection 16:525-531.

Datnoff, L.E., and Nagata, R.T. 1999. Influence of silicon on gray leaf spot development in St. Augustinegrass. Phytopathology 89:S19. (Abstr.)
Datnoff, L.E., Snyder, G.H., and Korndorfer, G.H. 2001. Silicon in Agriculture. Elsevier Science. Amsterdam, The Netherlands. 403 pp.

Freeman, T.E. 1962. Gray Leaf Spot Preys on St. Augustinegrass. Florida Agriculture Experiment State Research Report 7(2): 8-9.

Hamel, S.C., and Heckman, J.R. 1999. Impact of mineral silicon products on powdery mildew in greenhouse grown turf. Rutgers Turfgrass Proceedings, Rutgers, New Jersey. Volume 31:215-219.

Linjuan, Z., Junping, J., Lijun, W., Min, L., and Fusuo, Z. 1999. Effects of silicon on the seedling growth of creeping bentgrass and zoysiagrass. pp. 381. In: Datnoff, L.E., Snyder, and Korndorfer, G.H. (eds.) Silicon in Agriculture. Elsevier Science. Amsterdam, The Netherlands.

Savant N.K., Korndorfer, G.H., Datnoff, L.E., and Snyder, G.H. 1999. Silicon nutrition and sugarcane production: a review. Journal of Plant Nutrition 22(12): 1853-1903. 